\title{
Impact of Profit Tax on Employment in the Private Non-agricultural Sector in Albania
}

\author{
Shpresa Çela ${ }^{1} \&$ Albana Gjoni ${ }^{1}$ \\ ${ }^{1}$ Faculty of Economics and Agribusiness, Agricultural University of Tirana, Tirana, Albania \\ Correspondence: Shpresa Çela, Faculty of Economics and Agribusiness, Agricultural University of Tirana, Tirana, \\ Albania.
}

Received: December 14, 2020

Accepted: January 20, 2021

Online Published: February 9, 2021

doi:10.5430/rwe.v12n2p211

URL: https://doi.org/10.5430/rwe.v12n2p211

\begin{abstract}
In this paper we will analyze the employment rate in Albania, how it has changed over the years starting after the 1990s. For research reasons we have detached to analyze the employment rate in the private non-agricultural sector. Based on an analysis made by the World Bank and many other official sources such as the Labor Force Survey, the International Labor Organization (ILO) and official data such as INSTAT, we have noticed that employment in the Albanian market has become a problematic issue over the years because the employment rate has decreased. What are the factors that affect the employment rate? Does the profit tax rate have an effect on employment or not? We used an econometric model, linear regression to see the interdependence between these two variables using official data from 1995-2018. We have studied this period of time until 2018 where the situation has been normal, not including the COVID 19 crisis, which is an unusual period that in our opinion should be treated separately.
\end{abstract}

Keywords: number of employees in the private non - agricultural sector (NEPNAS), corporate tax rates, panel data analysis

\section{JEL: F21, H25}

\section{Introduction}

The effect of employment taxes is a highly debated economic and political issue. Some researchers argue that higher taxes lead to reduced employment, reducing the availability of the capital to be invested in job-creating enterprises, or reducing the amount of money available to consumers to buy goods and services, therefore causing a business loss for sellers of goods and services. Other researchers claim that higher taxes lead to higher employment because governments use that tax revenue to hire government employees, then employees buy goods and services from private businesses, and because governments themselves can act as consumers of goods and services. Higher taxes are also claimed to increase foreign investor confidence in government stability, and in the government's willingness and ability to pay off debts. But based on a scientific paper we have done, we have proved that in Albania, as a country which is considered to have a weak legal infrastructure and we have given the arguments why, we have proved that high taxes and more precisely a higher CIT (corporate income tax) directly affected the FDI (foreign direct investment) rate being associated with a strong negative correlation. (Note 1) So we have confirmed that with the increase of the tax rate, the level of FDI in Albania decreases. Also over the years it has been proven by various researchers that high taxes in one state or country will motivate businesses to move their operations to other states or countries with lower taxes. But how much tax cuts affect demand growth (or tax increases reduce demand) depends on the behavior sensitivity of family and business - for example, how families divide their increased income after tax between consumption and savings, and whether businesses choose to hire and invest more. According to the world literature, Laffer in 1974 argued that the economic effects of reducing incentives to work and invest by raising tax rates would be detrimental in the best of times and even worse in the midst of a stagnant economy, or with weak growth. Investors are less likely to risk their capital if their profits are taxed at a higher rate. A business is more likely to find ways to protect its capital from taxes by relocating all or part of its operations abroad. All of these together, could mean less total income, which come due to tax rates increase and this leads also to less emplyment rates. 


\section{Labor Market in Albania and Its Problems}

\subsection{Profit Tax in Albania}

Profit tax (Note 2) and the profit tax law generally date from the end of 1998 and have undergone numerous changes since. The standard profit tax rate according to the Ministry of Finance is 15\%, but small businesses with an annual turnover less than ALL 5 million are exempt from profit tax, while businesses with an annual turnover up to ALL 14 million are taxed at 5\%. The rate of $15 \%$ is lower than the EU average, but higher than the rate of the countries in the region such as Kosovo, North Macedonia and Montenegro. Losses can be carried forward for up to 3 years, while in Kosovo they can be carried forward for 6 years, in Bosnia, Serbia, Romania, Bulgaria, Hungary, Montenegro, Croatia and Italy for 5 years, in the Netherlands, Iceland, Finland for 10 years.

\subsection{Labor Market in Albania}

According to many studies conducted during the last decades, the employment rate in Albania has been declining after the 1990s. Before giving a clear picture of the labor market in Albania for which the determining factors are: labor force, employed, unemployed, working age population and inflows from its economically inactive component, where each of them presents their respectively specifics, we will detach the employment rate indicator, for the non-agricultural private sector. The main sources of information used to evaluate the labor market in Albania are: the first source refers to data collected through the Labor Force Survey (LFS) which produced the first results in 2007 on an annual basis, and by year 2012 also with quarterly frequency, the second source are administrative data which are available since 2000. Earlier information is also available in the World Bank data (Development Indicators), which have been available since 1990 on an annual basis. These data are only from the evaluations of the International Labor Organization (ILO) until 2000, while after 2000 are also included the evaluations of the Albanian Institute of Statistics (INSTAT). According to a study conducted by the World Bank in 2017, the employment rate for 1991, 2000, 2010 and 2016 results in a continuous decline. As can be noticed from the chart below, if we compare 2016 with 1991, the employment rate has dropped from $56.4 \%$ to $42.1 \%$, in other words, it has dropped by over 25 percent. While the opposite happened with the unemployment rate which increased from 1991 to 2016, reaching the highest unemployment rate of $16.3 \%$, which is the highest of the entire period under review. If we compare this value of unemployment with that of 1991 , we conclude that unemployment has increased by $23.5 \%$, values which make us understand that the employment market in Albania is problematic.

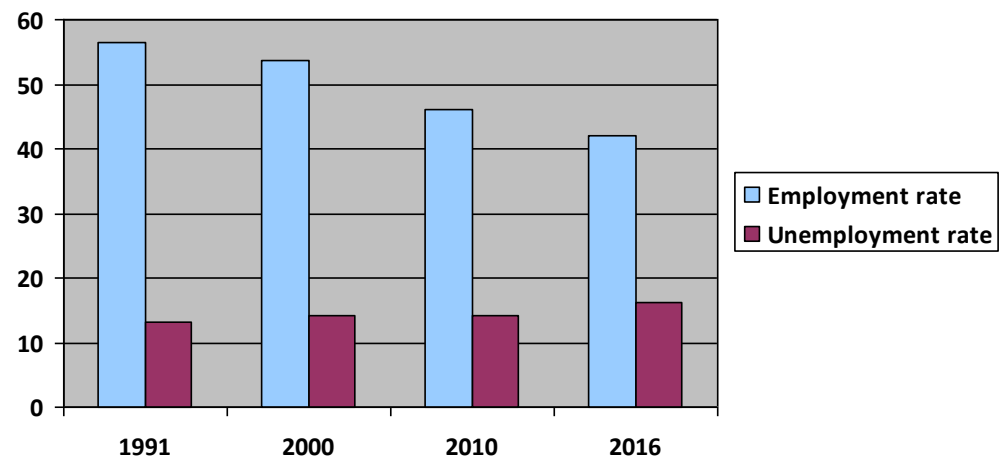

Figure 1. Employment and unemployment rates (\%)

Source: World Bank, 2017

If we refer to a research (Note 3) made by Open Data Albania, 1996 results the year with the largest number of employees who are officially registered for the period we have studied (1995 to 2018), where the number of employees goes to 1,138,000 employees, while the lowest number of employees was registered in 2014 with $1,037,000$, of which the agricultural sector and the services sector have the highest percentage of employees with respectively $42.7 \%$ and $39.4 \%$ of total employees. The structural fluctuation reflected in the decline of the employment rate in 2014, coincides in time with the lowest level of economic growth of the last 23 years, with an average growth of only 1.3\% in 2011 (second quarter) - 2014 (second quarter), as well as with the election campaign period of 2013. After 2014, although there is a slight increase until 2018, we can still say that the current level of 
employment results in $4.9 \%$ percentage points above the average level of these years but is still marginally below the level of 1996. According to a study conducted by the World Bank on employment in the Western Balkans region in 2016, it has been found that the number of employees for this year has reached 5.8 million people, of which 300,000 more than in 2010, but from all these, no additional job has been created in Albania. This is a worrying fact and therefore took our attention to analyze what are the causes for this problem. The World Bank proceeded by underlining that in Albania new jobs have experienced a decline of $2.4 \%$ and the largest decline has come to young people at $-36.4 \%$. Neighboring countries such as North Macedonia and Serbia have had a significant increase in new jobs, respectively by $12.5 \%$ and $11.2 \%$, but always measuring real employment. In Albania in 2015, the effect of formalization made by the government as a result of the anti-formality action was very high, but the World Bank measures real employment rates by not calculating this effect. For this reason, the data presented by the government are not the same as those of the World Bank. In this study we noticed a paradox in the employment structure in Albania, where during the period under evaluation, employment rate in the young age group has decreased and in the same time has increased for the older ones. As pointed out above, the largest decline occurred in young age groups 15-24 years with $-36.4 \%$, while for the age group $25-54$ years fell by $9.5 \%$, and the opposite occurred in employment for the age group 55-64 years, which had a 67\% increase. According to us, it is argued that in Albania there is a continuous and increased flow of emigration of young people from Albania to European Union countries, but the increased profit tax rate for businesses also has an impact, and according to the WB, it comes from the fact of aging population where the 55-64 age group is on the rise. According to this WB report, the unemployment rate fell in the whole region except in Albania. Unemployment fell to 1.5 million people in 2016 from 1.7 million in 2010, so it decreased by about 200,000 people, expressed in \% fell from 23\% in 2010 to $21 \%$ in 2016.

\subsection{Labor Market Problems in Albania}

\subsubsection{High Degree of Informality}

In this paper we have always referred to the official data especially of the WB, so in continuation of another study by the WB in cooperation with the Vienna initiative in the 2019 report on the Western Balkans, referring to the employment trend, noted that the total number of informal employees has increased in the region, and especially in Albania they represent $37 \%$ of the total number of employees even though there was an anti-formal action in 2013 by the government. So according to this report in our country, one in three people is working illegally, compared to 1 in 5 people in North Macedonia. So according to this report, the number of informal employees in the second quarter of 2018 has increased by 10,600 people compared to the second quarter of 2017. Informal employment is dominated by self-employment as well as unpaid family work. Informal self-employment and unpaid family work are more prevalent in the agricultural sector.

\subsubsection{High Employment in the Public Sector}

The population of Albania is officially decreasing, as we noted above. But according to data from both the WB and INSTAT, there is another reason for a decline in the number of employees in the private sector, even though it is often rumored by the government for a small administration, in reality the opposite has happened. The number of employees in the public sector has increased by 8,400 (Note 4). The number of employees in the public sector has increased by 8,400 people at the end of 2018, or by 5.1\% compared to 2017, so employees in 2018 reached 173000 people. Unlike the public sector the private sector added only 7,400 new jobs, an increase of $1.5 \%$ from 2016 . The number of employees in the private sector at the end of 2018 was approximately 509,000, from 502,000 a year ago. While in the last quarter of 2018, employment in the private sector fell by 9,400 people compared to the previous quarter.

The increase employees in public sector coincides with political elections where votes are exchanged for jobs in the local administration or public enterprises.

So comparing with European countries, according to the above data obtained from INSTAT, Albania has a high number of employees in the public sector compared to the total number of employees, excluding the agricultural sector. So it ranks approximately like the Nordic countries by passing the EU report which is $16 \%$. Employment in the Public sector in Albania represents 26.5 percent (excluding agriculture), so Albania ranks behind Sweden with $29 \%$ and Denmark with $28 \%$. 


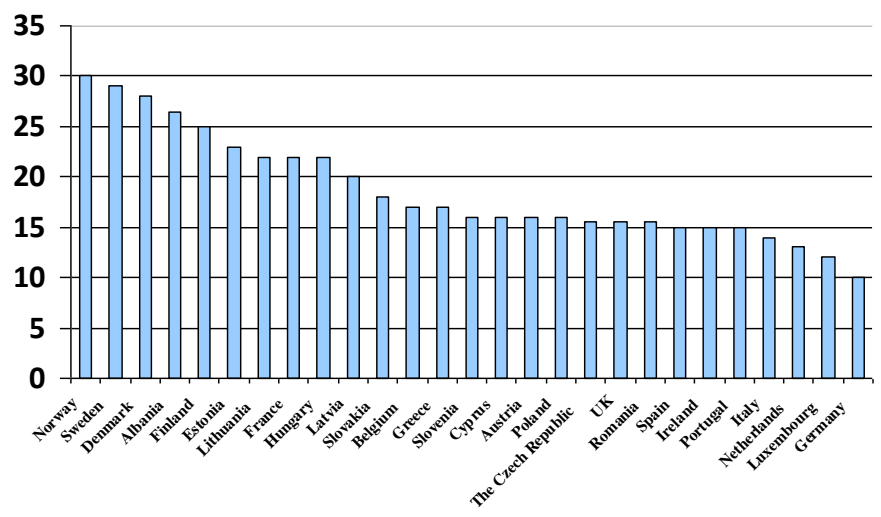

Figure 2. Public sector employment in \% of total employment in EU countries and Albania

\section{Analysis and Regression}

Hypothesis 1 . In countries with weak legal infrastructure, profit tax has a strong negative correlation and impact with employment in the non-agricultural private sector.

To analyze and validate the above hypothesis, so the relation between the corporate income tax rate and the number of employees in the non-agricultural private sector, we have constructed an econometric model, through the regression model.

In this relation, we have considered the corporate income tax rate as an independent variable, while the number of employees in the private non-agricultural sector (NEPNAS) as a dependent variable.

Based on the data obtained from the following table 4, which shows the rate of income tax applied in Albania from 1995 - 2018 and the number of employees in the private non-agricultural sector (NEPNAS) for this period of 23 years we have found the relation between these two variables which is expressed by the respective equation:

The regression equation is:

$$
\mathrm{y}=-9332.4 x+359403
$$

Nr. of Employees $=430.842 .75-936.466 .82 \mathrm{CIT}$

So:

y - Dependent variable (NEPNAS)

$\mathrm{x}$ - Independent variable (Corporate Income Tax)

Output:

Table 1. Regression analysis

\begin{tabular}{ll}
\hline Regression Statistics & \\
\hline Multiple R & 0.65 \\
\hline R Square & 0.42 \\
\hline Adjusted R Square & 0.39 \\
\hline Standard Error & $87,817.57$ \\
\hline Observations & 23.00 \\
\hline
\end{tabular}

$$
\begin{gathered}
S=87.817, R^{2}=65 \% \\
R^{2} \operatorname{adj}=39 \%
\end{gathered}
$$


Table 2. ANOVA

\begin{tabular}{llllll}
\hline & df & SS & MS & F & Significance F \\
\hline Regression & 1 & $116,438,751,243.17$ & $116,438,751,243.17$ & 15.10 & 0.00 \\
\hline Residual & 21 & $161,950,428,507.70$ & $7,711,925,167.03$ & & \\
\hline Total & 22 & $278,389,179,750.87$ & & & \\
\hline
\end{tabular}

Source: Author calculations

Table 3. Analysis of variance

\begin{tabular}{lllllllll}
\hline & Coefficients & $\begin{array}{l}\text { Standard } \\
\text { Error }\end{array}$ & $\begin{array}{l}\mathrm{T} \\
\text { Stat }\end{array}$ & P-value & Lower 95\% & Upper 95\% & Lower 95.0\% & $\begin{array}{l}\text { Upper } \\
95.0 \%\end{array}$ \\
\hline Intercept & $430,842.75$ & $50,388.40$ & 8.55 & 0.00 & $326,054.34$ & $535,631.16$ & $326,054.34$ & $535,631.16$ \\
\hline Intercept & $-936,466.82$ & $241,004.43$ & -3.89 & 0.00 & $-1,437,662.96$ & $-435,270.67$ & $-1,437,662.96$ & $-435,270.67$
\end{tabular}

Source: Author calculations

This is a first degree equation showing that the relation is linear. The value before $\mathrm{x}$ is negative which indicates that between the two variables exists a negative correlation, as well as the coefficient of determination $\mathrm{R}^{2}=0.65$ which shows a good approximation of the variables under consideration, we say good because it is not the total number of employees, but it is only the number of employees in the private non-agricultural sector. According to the data of the previous regression we can say that: CIT is important for determining the level of employment, and this is also very clear from the value of $\mathrm{p}=0.00$, that it is $<0.05$.

As shown in the following Graph 3. we can say that CIT has a strong negative correlation with the number of employees in the private non-agricultural sector ( NEPNAS). So the higher the corporate income tax rate in countries with poor legal and road infrastructure like Albania, the lower will be the number of employees in the private non-agricultural sector (NEPNAS).

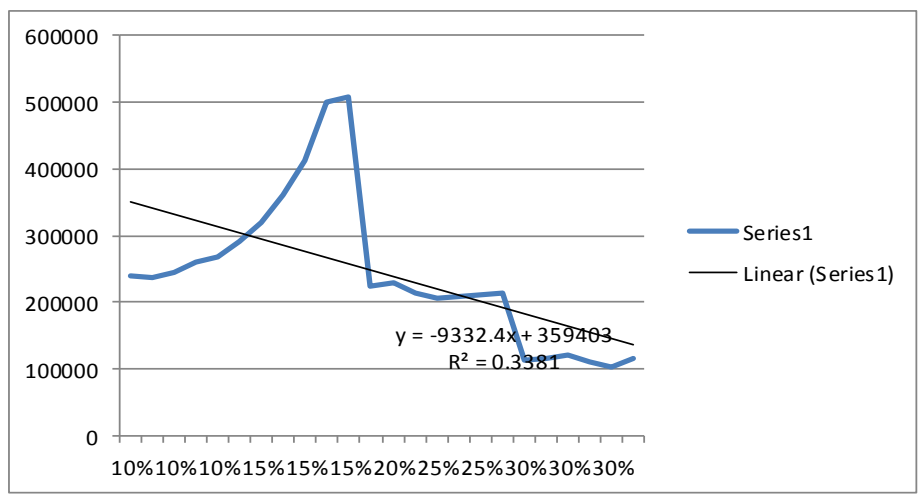

Figure 3. Number of employees in the non-agricultural private sector (NEPNAS) depending on Corporate Income Tax (CIT)

In this way we confirmed the above hypothesis that: In countries with weak legal infrastructure, the corporate income tax rate has a strong negative correlation and impact with the number of employees in the private non-agricultural sector (NEPNAS). 
Table 4. Data on relationship between number of employees in the non-agricultural private sector (NEPNAS) versus corporate income tax (CIT).

\begin{tabular}{lll}
\hline Year & CIT & Numri i të PSPJB \\
\hline $\mathbf{1 9 9 5}$ & $30 \%$ & $\mathbf{1 1 1 9 4 2}$ \\
\hline $\mathbf{1 9 9 6}$ & $30 \%$ & $\mathbf{1 1 5 9 1 0}$ \\
\hline $\mathbf{1 9 9 7}$ & $30 \%$ & $\mathbf{1 2 0 3 8 2}$ \\
\hline $\mathbf{1 9 9 8}$ & $30 \%$ & $\mathbf{1 1 1 3 5 4}$ \\
\hline $\mathbf{1 9 9 9}$ & $30 \%$ & $\mathbf{1 0 2 6 7 5}$ \\
\hline $\mathbf{2 0 0 0}$ & $30 \%$ & $\mathbf{1 1 6 0 2 4}$ \\
\hline $\mathbf{2 0 0 1}$ & $25 \%$ & $\mathbf{2 0 5 2 6 7}$ \\
\hline $\mathbf{2 0 0 2}$ & $25 \%$ & $\mathbf{2 0 7 7 4 2}$ \\
\hline $\mathbf{2 0 0 3}$ & $25 \%$ & $\mathbf{2 1 1 1 6 9}$ \\
\hline $\mathbf{2 0 0 4}$ & $25 \%$ & $\mathbf{2 1 3 0 0 0}$ \\
\hline $\mathbf{2 0 0 5}$ & $23 \%$ & $\mathbf{2 1 4 9 3 5}$ \\
\hline $\mathbf{2 0 0 6}$ & $20 \%$ & $\mathbf{2 2 4 0 5 8}$ \\
\hline $\mathbf{2 0 0 7}$ & $20 \%$ & $\mathbf{2 2 9 9 0 0}$ \\
\hline $\mathbf{2 0 0 8}$ & $10 \%$ & $\mathbf{2 3 8 9 7 5}$ \\
\hline $\mathbf{2 0 0 9}$ & $10 \%$ & $\mathbf{2 3 6 8 3 8}$ \\
\hline $\mathbf{2 0 1 0}$ & $10 \%$ & $\mathbf{2 4 4 2 5 5}$ \\
\hline $\mathbf{2 0 1 1}$ & $10 \%$ & $\mathbf{2 6 0 7 2 4}$ \\
\hline $\mathbf{2 0 1 2}$ & $10 \%$ & $\mathbf{2 6 8 6 9 0}$ \\
\hline $\mathbf{2 0 1 3}$ & $10 \%$ & $\mathbf{2 9 0 7 6 3}$ \\
\hline $\mathbf{2 0 1 4}$ & $15 \%$ & $\mathbf{3 1 8 5 7 9}$ \\
\hline $\mathbf{2 0 1 5}$ & $15 \%$ & $\mathbf{3 6 0 2 3 0}$ \\
\hline $\mathbf{2 0 1 6}$ & $15 \%$ & $\mathbf{4 1 2 4 7 3}$ \\
\hline $\mathbf{2 0 1 7}$ & $15 \%$ & $\mathbf{5 0 1 3 4 1}$ \\
\hline $\mathbf{2 0 1 8}$ & $15 \%$ & $\mathbf{5 0 8 7 2 8}$ \\
\hline & &
\end{tabular}

\section{Conclusions}

1. The results obtained from the various official reports published for the entire period under study, show that in Albania there are difficulties in securing employment and this is widely encountered for young people, as well as there is an non-optimal use of women's potential in the labor market, especially in the non-agricultural private sector.

2. From 2014 onwards, employment represents a slight, favorable and encouraging but not sufficient growth.

3. For the entire period under study there is a high presence of the informal market, which is dominated by self-employment, as well as unpaid family work. Informal self-employment and unpaid family work are more prevalent in the agricultural sector. For this reason, there is a need for a government policy that should reduce this phenomenon.

4. Comparing it with European countries according to the above data obtained from INSTAT, Albania has a high number of employees in the public sector compared to the total number of employees excluding the agricultural sector. So in our opinion, countries with fragile economies and high corruption like Albania should have a limited number of employees in public administration, giving priority to increasing employment in the private sector.

5. From the econometric model we applied to study the relation between the level of employment and the level of corporate income tax, we concluded that the higher the tax rate the lower the level of employment in the private non-agricultural sector, for this reason we belive that profit tax rates in countries with weak legal infrastructure like Albania should be as low as possible in order to have an increase in the level of employment. 
6. One of the most important developments in recent years for the labor market in Albania was the return of emigrants caused mainly by the financial crisis of 2008, where the difficult economic situation of the host countries of Albanian emigrants, made a large part of them to return to the country again, seeking to be included in the labor market. This category requires the undertaking of concrete policies, such as fiscal facilities, professional training or consulting for this category so that they can have an integration in the labor market as soon as possible.

7. Unemployment has also increased significantly as a result of the COVID-19 crisis. Albania has registered the largest increase in the number of unemployed compared to other Western Balkan countries, by $25 \%$ until April 2020, followed by Northern Macedonia by $11 \%$.

8. The highest negative impact of COVID 19 will influence the private sector, therefore the non-agricultural employees of the private sector. So we think that the Albanian government should take helpful and mitigation measures to recover this sector, helping the enterprises to maintain or create new jobs, through various fiscal incentives, such as lowering the profit tax rate.

\section{References}

Çela, S. (2017). The effect of company profit tax on attracting foreign direct investment in Albania. International Journal of Financial Research, 192.

Eerebara, G. (2019). Public administration is inflated, slow employment growth in the private sector. Reporter.al Journal. Retrieved from https://www.reporter.al/fryhet-administrata-publike-rritje-e-ngadalte-e-punesimit-ne-sektorin-privat

INSTAT. (2019). Retrieved from http://www.instat.gov.al/

Ministry of Finance. (2019). Law Nr. 8438, Dated 28.12.1998 Income Tax, changed.

Open Data Albania. (2018).

Retrieved from https://www.monitor.al/shqiperia-nder-vendet-europiane-numrin-te-larte-te-punonjesve-ne-shtet/

Te Fundit nga Vendi. (2018). Albania, among the European countries has the highest number of employees in public sector. Monitor Magazine. Retrieved from

World Bank. (2017).

World Bank. (2019). The World Bank in cooperation with the Vienna Initiative in the 2019 report.

\section{Notes}

Note 1. Shpresa Çela, (2017) The Effect of Company Profit Tax on Attracting Foreign Direct Investment in Albania, International Journal of Financial Research, 192.

Note 2. Ministry of Finance 2019, Law Nr. 8438, Dated 28.12.1998 Income Tax, changed.

Note 3. Open Data Albania 2018

Note 4. INSTAT 2019 http://www.instat.gov.al/

\section{Copyrights}

Copyright for this article is retained by the author(s), with first publication rights granted to the journal.

This is an open-access article distributed under the terms and conditions of the Creative Commons Attribution license (http://creativecommons.org/licenses/by/4.0/). 